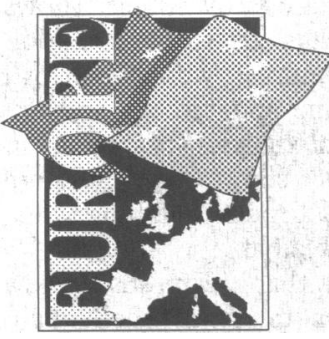

This is the fifteenth and final in a series of articles looking at medical issues in Europe

\section{European research: back to pre-eminence?}

Richard Smith

Europe has an unequalled tradition in scientific research. Most of the important discoveries in science before 1900 were made by Europeans in Europe. Britain, France, Germany, Italy, the Netherlands, and Switzerland had between them won $45 \%$ of all Nobel prizes from their inception until 1985-compared with the $39 \%$ won by Americans (table I). ${ }^{1}$ Over those years Europeans compared with the Americans won twice as many Nobel prizes for chemistry, slightly more for physics, but fewer for physiology and medicine.

Although having strong traditions in research Britain, Germany, and France won most of their Nobel prizes in the early years of the century. The decline is most marked in Britain. Indeed, between 1986 and 1991 the United States won 22 prizes, the Germans nine, the Swiss three, the French two, and the British only one. ${ }^{2}$ In terms of prizes per head of population from 1980 to 1991 the world order was the United States first followed by Germany, Sweden, Denmark, and then Switzerland. ${ }^{2}$

The hope in Europe is that the European Community and other bodies coordinating research across Europe will be able to produce greater collaboration and so eventually return Europe to the first place in science. In addition, research is vital for economic development, and better collaboration in research should increase the industrial competitiveness of Europe. But getting the countries of Europe to collaborate in research is by no means simple.

\section{Inputs and outputs in European research}

Altogether the countries of the European Community spend about US $\$ 90000 \mathrm{~m}$ a year on researchconsiderably less than the $\$ 144000 \mathrm{~m}$ spent in the United States but more than the $\$ 57000 \mathrm{~m}$ spent in Japan (table II). ${ }^{3}$ The expenditure per head of population (\$201) is much less than that of both the United States (\$582) and Japan (\$469). The European countries spending the most on research are unsurprisingly those with the largest economies, with the Germans spending the most in absolute terms and the most per head of population (\$431). Table II shows a clear divide in expenditure on research between the richer and poorer countries in Europe: Greece, Ireland, Portugal, and Spain all spend under $\$ 90$ per head, whereas all the other countries spend over $\$ 170$. Table

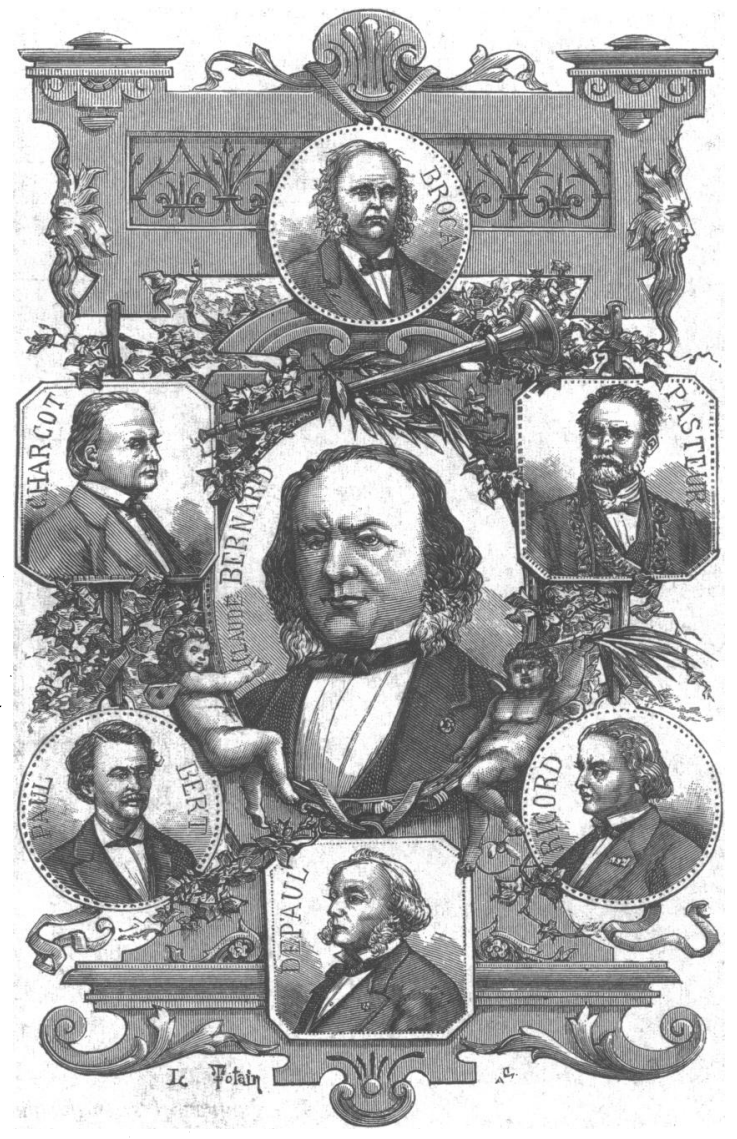

French genius on the wane?

III shows the growth (or in the cases of Ireland and the Netherlands contraction) in expenditure on research by country for 1989: with an average expansion of $4 \cdot 7 \%$ the European Community is running ahead of growth in the United States $(2 \cdot 3 \%)$ but behind growth in Japan $(9 \cdot 1 \%)$.

Total expenditure on health research in the European Community $(\$ 2045 \mathrm{~m})$ is less than a quarter of the expenditure in the United States, meaning that the Americans spend more than eight times as much per head on health research as the Europeans (table IV). ${ }^{4}$ (The most surprising figure in the table is for Denmark,

TABLE I - Nobel prizes by country, 1900-91

\begin{tabular}{|c|c|c|c|c|c|c|c|c|c|c|}
\hline & France & Germany & Italy & Netherlands & Switzerland & $\begin{array}{c}\text { United } \\
\text { Kingdom }\end{array}$ & Japan & $\begin{array}{l}\text { United } \\
\text { States }\end{array}$ & Rest & Total \\
\hline \multicolumn{11}{|c|}{ Physiology and Medicine } \\
\hline $1901-1930$ & 4 & 5 & 1 & 2 & 1 & 3 & 0 & 2 & 11 & 29 \\
\hline $1930-1965$ & 3 & 5 & 1 & 0 & 3 & 12 & 0 & 27 & 10 & 61 \\
\hline $1966-1985$ & 1 & 2 & 0 & 0 & 1 & 7 & 0 & 33 & 7 & 51 \\
\hline 1986-1991 & 0 & 2 & 1 & 0 & 0 & 1 & 1 & 7 & 0 & 12 \\
\hline \multicolumn{11}{|l|}{ Chemistry } \\
\hline $1901-1930$ & 4 & 12 & 0 & 1 & 1 & 5 & 0 & 1 & 4 & 28 \\
\hline $1930-1965$ & 2 & 9 & 1 & 1 & 2 & 10 & 0 & 13 & 5 & 43 \\
\hline $1966-1985$ & 0 & 3 & 0 & 0 & 1 & 8 & 1 & 15 & 4 & 32 \\
\hline $1986-1991$ & 1 & 3 & 0 & 0 & 1 & 0 & 0 & 7 & 1 & 13 \\
\hline \multicolumn{11}{|l|}{ Physics } \\
\hline $1901-1930$ & 6 & 10 & 1 & 4 & 1 & 7 & 0 & 3 & 4 & 36 \\
\hline $1930-1965$ & 0 & 5 & l & 1 & 0 & 8 & 2 & 25 & 8 & 50 \\
\hline $1966-1985$ & 2 & 1 & 1 & 1 & 0 & 6 & 0 & 24 & 5 & 40 \\
\hline 1986-1991 & 1 & 4 & 0 & 0 & 2 & 0 & 0 & 8 & 0 & 15 \\
\hline Total & 23 & 57 & 7 & 10 & 11 & 67 & 4 & 157 & 59 & 395 \\
\hline
\end{tabular}

British Medical Journal, London WC1H 9JR Richard Smith, editor

BMF 1992;304:899-903 
TABLE II-Gross expenditure on research in European Community, United States, and Japan and expenditure per head of population, 1989

\begin{tabular}{lcc}
\hline Country & $\begin{array}{c}\text { Expenditure } \\
\text { on research } \\
\text { (US\$m) }\end{array}$ & $\begin{array}{c}\text { Expenditure } \\
\text { on research } \\
\text { per head } \\
\text { (US\$) }\end{array}$ \\
\hline Belgium & 2059 & 208 \\
Denmark & 1147 & 223 \\
France & 21052 & 342 \\
Germany & 28418 & 431 \\
Greece & 339 & 34 \\
Ireland & 268 & 73 \\
Italy & 12095 & 173 \\
Netherlands & 4412 & 297 \\
Portugal & 328 & 32 \\
Spain & 3722 & 77 \\
United Kingdom & 18485 & 323 \\
\hline European Community total & 92325 & 201 \\
\hline United States & 144820 & 582 \\
Japan & 57740 & 469
\end{tabular}

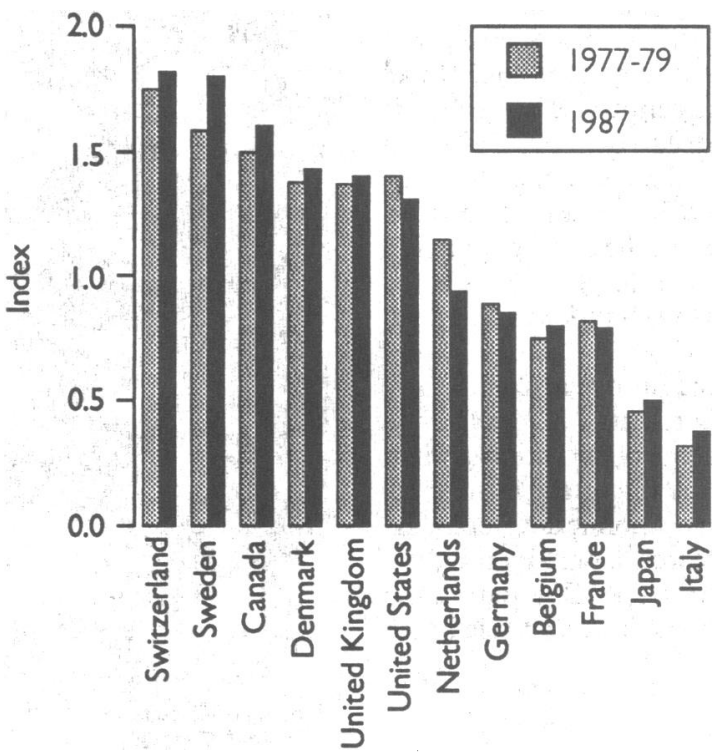

FIG 1-Number of scientific publications per head of population (various countries, situations 1977-9 and 1987). Comparison is with number of publications per head for the Netherlands in 1987, which is thus given the index of 1

where Organisation for Economic Cooperation and Development data show that expenditure on health research has fallen from $\mathrm{Kr} 243 \mathrm{~m}$ in 1986 to $\mathrm{Kr} 80 \mathrm{~m}$ in 1990.)

How much do European countries have to show for their expenditure on research? Science policy experts have various measures of "output," including numbers of publications, citations, patents applied for, and Nobel prizes. (A 300 page report on such data is currently being prepared for the European Commission.) Table $V$ shows the number of patents applied for by nationals of the various European countries and Japan in the United States in 1989. ${ }^{1}$ Together all the countries of the European Community applied for fewer patents than Japan alone, which suggests that the Japanese are much better than any European nation-except the Germans, who also had a high rate in terms of population - at turning scientific ideas into products.

Publication data are less easy to find for all European countries but figure 1 shows that the Swiss and the Swedes lead the world in numbers of scientific publications per head of the population. ${ }^{5}$ Figure 2 shows world share of scientific publications, with the Americans contributing a massive $35 \%$; the British, Germans, French, and Dutch between them contribute $23 \% .^{6}$ When it come to citations the Americans dominate even more, accounting for $51 \%$ of citations, while the British, Germans, French, and Dutch account for $21 \%$ (fig 3). In clinical medicine the Americans produce $40 \%$ of publications and $54 \%$ of citations, while the British, Germans, French, and Dutch produce $27 \%$ of publications and $19.9 \%$ of citations. ${ }^{6}$ An analysis of citations by subject shows that the French and Germans are both strong in chemistry, physics, and mathematics, while the British are strong in clinical medicine and biology and the Dutch in mathematics. ${ }^{6}$ An analysis of trends in citations between 1983 and 1986 shows the world share of the Germans, British, and French is falling while that of the Dutch has stayed steady. ${ }^{6}$

Generally these figures show that Europeans spend a lot on research, but not as much as their main competitors, and that they produce good results - but again not as impressive as their main competitors. The hope is that the European Community will eventually be able to produce a bigger bang for the research ecu by bringing the research efforts together.

\section{Networks of European research}

The European Community is not the only organisation trying to bring scientists together in Europe. Science has always been an international activity, and many networks link scientists together across Europe. Many form personal links through travelling to international conferences, corresponding, and reading the same journals, and an increasing number are linked by electronic networks. There are, in addition, a host of societies covering most of the major scientific interests.

Despite these networks there is a need for larger organisations, and a good example is the Centre Européen de Recherche Nucléaire. It was founded in 1954 to bring European particle physicists together and give them the facilities to practise their expensive science. It effectively saved European high energy physics from extinction and showed that European countries could cooperate on a scientific endeavour

TABLE IV-Total expenditure on health research for 1990 together with expenditure per head of population

\begin{tabular}{lcc}
\hline & $\begin{array}{c}\text { Total } \\
\text { expenditure } \\
\text { (US\$m) }\end{array}$ & $\begin{array}{c}\text { Expenditure } \\
\text { per head } \\
\text { (US\$) }\end{array}$ \\
\hline Belgium & 30 & 3 \\
Denmark & 13 & 2 \\
France & 494 & 9 \\
Germany & 498 & 8 \\
Greece & 12 & 1 \\
Ireland & 4 & 6 \\
Italy & 332 & 4 \\
Netherlands & 60 & 1 \\
Portugal & 6 & 4 \\
Spain & 144 & 8 \\
United Kingdom & 451 & $4 \cdot 27$ \\
\hline European Community & 2044 & $34 \cdot 46$ \\
\hline United States & 8572 &
\end{tabular}

TABLE V-Total applications for patents filed by foreign nationals in the United States in 1988 together with number per 100000 population

\begin{tabular}{lcc}
\hline & & $\begin{array}{c}\text { Patent } \\
\text { applications } \\
\text { per 100000 } \\
\text { population }\end{array}$ \\
\hline Belgium & 588 & $5 \cdot 92$ \\
applications & $10 \cdot 42$ \\
France & 535 & $8 \cdot 73$ \\
Germany & 4902 & $20 \cdot 15$ \\
Greece & 12493 & $0 \cdot 29$ \\
Ireland & 29 & $2 \cdot 93$ \\
Italy & 103 & $3 \cdot 64$ \\
Netherlands & 2096 & $10 \cdot 86$ \\
Portugal & 1613 & $0 \cdot 07$ \\
Spain & 7 & $0 \cdot 59$ \\
United Kingdom & 231 & $10 \cdot 14$ \\
\hline European Community total & 5805 & $8 \cdot 72$ \\
\hline Japan & 28402 & $24 \cdot 05$
\end{tabular}
growth or contraction in gr

Greece

Ireland

Netherland

Portugal

United Kingdom

European Community

$\begin{array}{ll}\text { average } & 4.73\end{array}$

United States 


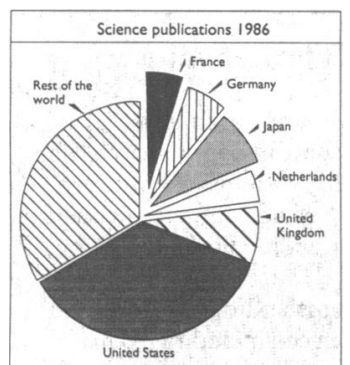

FIG 2-National shares of world science publications, 1986

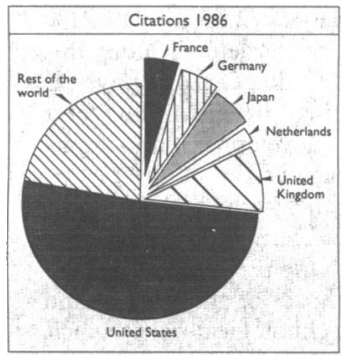

FIG 3-National shares of world citations, 1986 that was beyond the means of individual countries. The European Molecular Biology Organisation was founded on a similar model in $1963 .^{7}$ The founders of the organisation, who included John Kendrew, the Nobel prize winning molecular biologist from Cambridge, were "deeply concerned that the initiative in molecular biology was by 1962 passing rapidly to the USA from Europe, where many of the early key discoveries had been made." They were "convinced that Europe could only play its accustomed role in the far reaching intellecutal movement that molecular biology represented if the individual countries pooled at least some of their national resources in this field of research." The private self governing organisation now has 700 molecular biologists as members and a laboratory in Heidelberg. It works by encouraging and funding interactions among European molecular biologists.

Another important grouping of European scientists is the European Science Foundation. The foundation has 56 member research councils, academies, and institutions from 20 countries. Funded by contributions from its members, the foundation "brings European scientists together to work on topics of common concern, to co-ordinate the use of expensive facilities, and to discover and define new endeavours that will benefit from a co-operative approach." Scientists like the foundation because-in contrast with the European Commission programme-it is led by scientists and academics and members can opt in or out of particular programmes: its menu is à la carte. But, as one observer of the foundation told me, "Its organisation is fantastically complex-only scientists could have created it."

Included within the European Science Foundation is a standing committee of the European Medical Research Councils that covers 13 national research councils. It has no budget, no sanctions, and only a small secretariat but allows the research councils to get together and discuss issues like training, the state of clinical research, data protection, and ethical issues.

Another important European body that is showing an increasing interest in research-particularly the ethical aspects - is the Council of Europe. Any interest in research is welcomed by the scientific community, but the proliferation of European bodies interested in research may mean that the energy that should come from strategically concentrating resources may be lost.

\section{Research and the European Community}

If any organisation in Europe can achieve widespread European cooperation in research that body is the European Commission. The European Community was born with two main aims - to prevent another war in Europe and to bring the countries of Europe

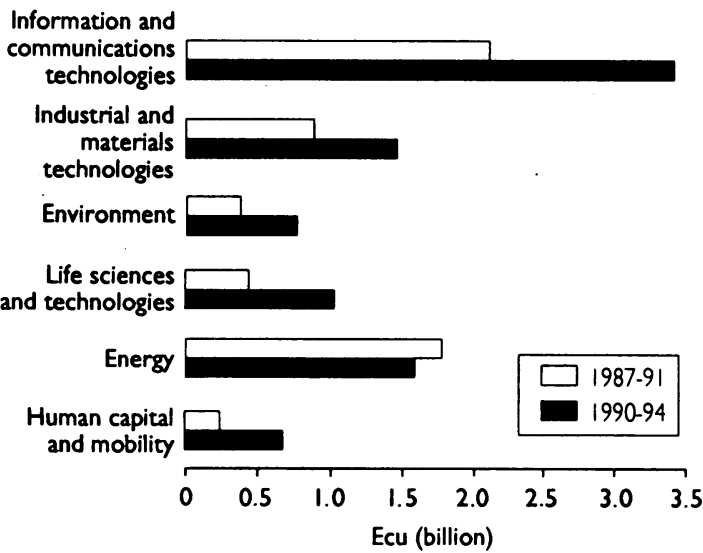

FIG 4-European Community expenditure on research under second and third framework programmes
TABLE VI-European Community research and development third framework programme 1990 to 1994

\begin{tabular}{|c|c|c|}
\hline Programme & $\underset{\text { (millions) }}{\text { Ecu }}$ & $\stackrel{\mathfrak{E}}{\text { (millions) }}$ \\
\hline \multicolumn{3}{|c|}{ Information technology and telecommunications: } \\
\hline Information technology & 1352 & 942 \\
\hline Communication technology & 489 & 341 \\
\hline Telematics & 380 & 265 \\
\hline \multicolumn{3}{|l|}{ Industrial and materials technologies: } \\
\hline Industrial materials technology & 748 & 521 \\
\hline Measurement and testing & 140 & 98 \\
\hline \multicolumn{3}{|l|}{ Environment: } \\
\hline Environment & 414 & 289 \\
\hline Marine science and technology & 104 & 72 \\
\hline \multicolumn{3}{|l|}{ Life sciences and technologies: } \\
\hline Biotechnology & 164 & 114 \\
\hline Agriculture and agroindustrial research & 433 & 232 \\
\hline Biomedical and health research & 133 & 93 \\
\hline Science and technology for developing & & \\
\hline countries & 114 & 77 \\
\hline \multicolumn{3}{|l|}{ Energy: } \\
\hline Non-nuclear energies & 157 & 109 \\
\hline Nuclear fission safety & 199 & 139 \\
\hline Fusion & 458 & 319 \\
\hline Human capital and mobility & 518 & 361 \\
\hline Total & 5700 & 3972 \\
\hline
\end{tabular}

¿Central exchange rate mechanism: $1 \cdot 435 \mathrm{ecu}=£ 1$.

together so that they could compete effectively with the United States and Japan. Research can contribute to both of these aims. In the early days research was conducted almost entirely in the subjects that were of particular interest to the community - coal, steel, and nuclear energy. ${ }^{8}$ In the early ' 80 s the community began programmes designed to coordinate research-the framework programmes - but it was the Single European Act of 1987 that gave a real boost to research and development. That revision of the Treaty of Rome led to research and technological development being given the same status as economic and social policy. Figure 4 shows how funding has grown from the second research framework programme, which ran from 1987 to 1991 , to the third, which runs from 1990 to 1994 .

Because the Treaty of Rome did not cover health and biomedical research has never been a large part of the community's research effort, but it is now growing. The programme is run by directorate general XII - the directorate for science, research, and developmentand it began in 1978. At that time only three projects were supported, and the budget was $1.09 \mathrm{~m}$ ecu.

The idea of the framework programmes, which began in 1984, is to bring researchers from different countries together to do largely precompetitive research. "The intention," says the commission, "is to deal only with projects that can be carried out more rationally, cost effectively and more efficiently at European level." " Research funds are thus largely devoted to coordination rather than funding particular projects, a point which some of those seeking grants have been slow to grasp.

The biomedical and health research programme (known as BIOMED) is one of the smallest of the 15 research programmes being run by the commissiontable VI shows all the programmes. BIOMED has a budget of $133 \mathrm{~m}$ ecu, which is only $2 \cdot 3 \%$ of the total research budget. The chief objective of BIOMED "is to contribute to improving the effectiveness of research and development in medicine and health in the member states, in particular through better coordination of their research and development activities, to applying their findings through community cooperation and to using available resources in common." Table VII shows how the scale of European Community medical research has grown since its inception. It has grown exponentially at a time when most national research programmes have expanded little or not at all. The proportion of national research funds devoted to European Community research is still tiny, but the present changing patterns suggest that eventually most research will be conducted on a European scale. 
TABLE VII -Growth in medical and health research in the European Community

\begin{tabular}{lcccc}
\hline Programme & Duration & $\begin{array}{c}\text { No of } \\
\text { projects }\end{array}$ & $\begin{array}{c}\text { No of } \\
\text { national } \\
\text { teams }\end{array}$ & $\begin{array}{c}\text { Ecu } \\
\text { (millions) }\end{array}$ \\
\hline First & $1978-81$ & 3 & 100 & $1 \cdot 09$ \\
Second & $1980-83$ & 7 & 230 & $2 \cdot 32$ \\
Third & $1982-86$ & 34 & 1400 & $13 \cdot 3$ \\
Fourth & $1987-91$ & 140 & 4500 & 65 \\
Fifth & $1990-94$ & $\geqslant 200$ & $\geqslant 5000+$ & 133 \\
\hline
\end{tabular}

The rapid growth of the European programme has, however, caused difficulties for the small numbers of staff who have overseen the programme since the beginning.

\section{ORIGINS OF A PROGRAMME}

The way that a programme arises is complex and slow, and is summarised in figure 5. The proposal arises in the commission and is ultimately carried out by the commission, but it spends some two years going backwards and forwards between the commission, the parliament, and all three levels of the Council of Ministers. That is why applications are only now being processed for the framework programme that was due to begin in 1990. The complexity and slowness of the process is an important problem, but unfortunately the British blocked proposals to simplify and speed up the process at the European Community summit meeting in Maastricht last year. The process of finalising a programme gives ample scope for political horsetrading, and substantial changes may be made. Thus Alain Pompidou, the Frenchman who is rapporteur of the research committee in the parliament, managed to have biomedical ethics included as a main target area in the programme.

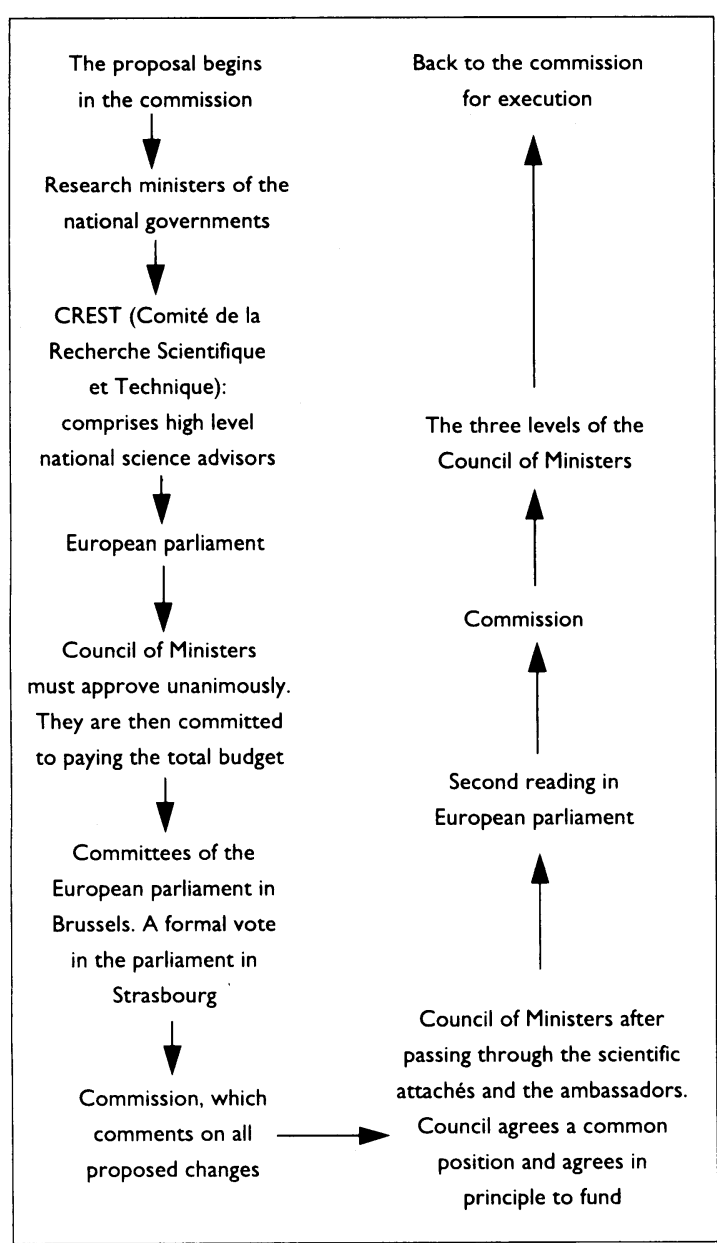

FIG 5-Long, slow journey through Europe of a proposal for a European Community research programme

\section{Scope of the BIOMED programme.}

BIOMED has four main target areas as follows:

Area 1-Development of coordinated research on prevention, care and health systems: $27.5 \mathrm{~m} \mathrm{ecu}$, $21 \%$ of the programme. Specific targets include: drugs, occupational health, biomedical technology, health services research

Area 2-Major health problems and diseases of great socioeconomic impact: $72 \mathrm{~m}$ ecu including $25 \mathrm{~m}$ ecu for AIDS, $54 \%$ and $19 \%$ of the programme respectively. Specific targets include: AIDS, cancer, mental illness and neurological disease, cardiovascular disease, and aging and age related problems

Area 3-Human genome analysis: $27.5 \mathrm{~m} \mathrm{ecu}, 21 \%$ of the programme. Specific targets include: improvement of the genetic (linkage) map, physical mapping, DNA sequencing, data handling and databases, and technology development and applications of human genome analysis

Area 4-Research on biomedical ethics: $4.6 \mathrm{~m} \mathrm{ecu}$, $3.5 \%$ of the programme. This will cover both ethical questions related to the programme and the evaluation of the social impact of the programme and the risks (including technological risks) which might be associated with it.

The programme has four main target areas: prevention, care and health systems ( $21 \%$ of expenditure); 을 major health problems and diseases of great socioeconomic impact (54\%); human genome analysis (21\%); and biomedical ethics $(3 \cdot 5 \%)$. The box shows the topics covered in the programme. The programme $\vec{\otimes}$ is particularly interested to encourage health services ? research, multidisciplinary teams where local skills are 0 in short supply, clinical trials, targeted research where coordination is needed (for instance, research into AIDS or the human genome), and training. "In effect," says Gillian Breen, head of the international $\stackrel{\circ}{\circ}$ section at the Medical Research Council, "almost anything has a chance of getting funded."

Everything except the work on the human genome is supported primarily through concerted action $\frac{\vec{F}}{0}$ contracts. These meet $100 \%$ of the costs of coordination and cover activities like organising meetings and scientific support, distributing material and data, short term exchanges of staff, and dissemination of results. $\frac{\dot{\sigma}}{7}$ Shared cost contracts are for the human genome work and cover $50 \%$ of the full costs of the project or $100 \%$ of the marginal costs. These contracts are open to everybody and all organisations in the member states, $\frac{9}{9}$ but applications have to be made by partners from at $N$ least two member states. Austria, Finland, Norway, Sweden, Switzerland, and Turkey are all continuing an association with the programme and more countries are expected to join, with Czechoslovakia, Hungary, Iceland, and Poland all now eligible.

\section{APPROVING PROJECTS}

The system used for approving projects in the second framework was severely criticised by a group? from York University appointed by the commission to $\frac{0}{0}$ evaluate the medical and health research programme. ${ }^{10} \stackrel{\mathbb{D}}{\stackrel{D}{0}}$ The group said that many scientists in Europe knew $\frac{?}{\mathbb{Q}}$ nothing about the programme and did not know how to $\varrho$ get grants from the commission; that the peer review system was below acceptable standards; and that the 8 money would be better spent on a few centres of excellence rather than on paying people to coordinateo with each other. The commission responded by? improving its peer review systems.

The peer review system to be used in the third framework programme is currently being developed. The call for applications finally went out at the end of September 1991, and they were due in by the end of 
January 1992. Some 1900 applications were received, many more than for previous programmes. These are not full applications but outline proposals, and the commission aims to reduce them to about 250 in the next stage. The authors of these applications, which must come from more than one country, will then be invited to submit full proposals.

The outline proposals are about six to eight pages long and comprise one page summarising the current state of the proposed research subject; two pages on what is proposed; an explanation of why the application is being made through Brussels; a list of the participating teams; and a timetable and budget. These applications have been looked at by a series of panels consisting of 18 people (one from each country) divided into five disciplines: cell and molecular biology; physiology and clinical medicine; epidemiology and clinical trials; health services research; technology development and ethics. The panels have been put together from 750 names, nearly all proposed by the 18 countries, but they are anonymous-not even the Committee of an Advisory Nature on Biomedical and Health Research, the expert body which advises the secretariat running the programme, knows who individual panel members are.

The panels have scored the proposals on seven different criteria; scientific excellence and originality; relevance to the programme; transnational collaboration; the complementarity of the participating teams; the competence of the teams; the feasibility of doing the work within the three years available; and the potential for exploitation. The ethical and health and safety aspects of the proposals are also considered. The panels give a score to each of the proposals, which are then ranked and presented to the Committee of an Advisory Nature. The committee, which is meeting in the week that I write, has been presented with some 200 applications in category A with the recommendation that these all proceed to the next stage and some 1600 in category $\mathrm{C}$ with the recommendations that they will not be funded. The committee will probably spend its time debating the 100 in the middle, deciding which will go forward. At the end of the process about 100 projects can be funded.

In the next stage new subcommittees will be formed, the members of which will not be anonymous. There will again be one representative from each country with possible additions representing particular scientific interests. The subcommittees will be aiming at matching the applications with the budget allocations. The Committee of an Advisory Nature will meet in June to make the final recommendations, but there will then be a second round of applications, with a closing date in January 1993.

\section{TOP DOWN AND BOTTOM UP}

The second stage of this complex process still has to take place, but it is obviously tricky to fit together detailed instructions from above about what should be in the programme with the applications coming from the scientists in Europe. The chance of all the best applications fitting into the preordained programme must be almost nil. Inevitably there will have to be compromises on scientific quality in order to squeeze the applications into the various sectors. There are not, however, any priorities attached to the many parts of the programme, and the commission has been anxious to avoid such priorities - they might prove to be an impossible straitjacket.

Scientists are also inevitably suspicious of a funding process so dominated by political concerns. The politicians are prominent in deciding what should be in the programme, and then the peer review committees are structured to have one person from each country on each committee: it seems unlikely that those will be the best people that the community could produce to assess papers.

A final problem with the process is the shortage of staff to run the programme. It may seem strange to argue that there are too few bureaucrats in Brussels, but the 14 staff running the last $80 \mathrm{~m}$ ecu programme were overstretched and the problems are likely to be worse with only 18 staff running a $133 \mathrm{~m}$ ecu programme.

\section{Conclusion}

Europe has in the past been pre-eminent in science and technology, but it has now lost that pre-eminence to the Americans and the Japanese. The standard and productivity of European science could almost certainly be improved by increasing collaboration among scientists in Europe. Various bodies exist to increase that collaboration, but the organisation best positioned to increase it dramatically is the European Community. Unfortunately, its processes for funding biomedical research are slow, tortuous, and muddy and need to be considerably improved before European nations will be willing to allow large parts of their research budgets to be spent through Europe. But that is surely what will need to happen in the end if European science is to be brought back to preeminence.

1 Advisory Board for the Research Councils, Royal Society, Economic and Social Research Council. Evaluation of national performance in basic research. London: ABRC, 1986.

2 Martin BR, Irvine J. The position of British science. Nature 1992;355:760.

3 Organisation for Economic Cooperation and Development. Main science and technologv indicators. Paris: OECD, 1991

4 Organisation for Economic Cooperation and Development. Basic science and technology indicutors. Paris: OECD, 1991.

Van Heeringen A, Langendorff ANM. Science and technology indicators. Hague: Advisory Council for Science Policy, 1989.

6 Martin BR, Irvine J, Narin F, Sterritt C Stevens KA Recent trends in the output and impact of British science. Science and Public Policy 1990;17: outpu

7 European Molecular Biology Organisation. European Molecular Biology Organisation 1964-1989. Heidelberg: EMBO, 1989

8 Commission of the European Communities. EC research funding Brussels: EC 1990.

9 Maynard A, ed. Evaluation of the fourth medical and health research programme. Brussels: European Commission, 1990

10 Richards T. European research. BMJ 1990;301:950 